\title{
Galanin enhances corticosterone secretion from dispersed rat adrenocortical cells through the activation of GAL-R1 and GAL-R2 receptors coupled to the adenylate cyclase-dependent signaling cascade
}

\author{
PAOLA G. ANDREIS ${ }^{1}$, LUDWIK K. MALENDOWICZ ${ }^{2}$, PIERA REBUFFAT ${ }^{1}$, RAFFAELLA SPINAZZI $^{1}$, \\ AGNIESKA ZIOLKOWSKA ${ }^{2}$ and GASTONE G. NUSSDORFER ${ }^{1}$ \\ ${ }^{1}$ Department of Anatomy and Physiology, Section of Anatomy, University of Padua, I-35121 Padua, Italy; \\ ${ }^{2}$ Department of Histology and Embryology, Poznan School of Medicine, Poznan PL-60781, Poland
}

Received July 13, 2006; Accepted September 21, 2006

\begin{abstract}
Galanin is a regulatory peptide, which acts via three subtypes of receptors, named GAL-R1, GAL-R2 and GAL-R3. Reverse transcription-polymerase chain reaction demonstrated the expression of GAL-R1 and GAL-R2, but not GAL-R3 mRNAs in dispersed rat adrenal zona fasciculatareticularis (inner) cells. The immuno-blockade of GAL-R 1 and GAL-R2, but not GAL-R3, decreased the binding of $\left[{ }^{3} \mathrm{H}\right]$ galanin to dispersed cells, a complete inhibition being obtained only by the simultaneous blockade of both receptor subtypes. Galanin stimulated corticosterone and cyclic-AMP release from dispersed inner rat adrenocortical cells, while inositol triphosphate production was not affected. Again these responses to galanin were reversed by both the GAL-R 1 and GAL-R2, but not the GAL-R3 immuno-blockade. The adenylate cyclase inhibitor SQ-22536 and the protein kinase (PK) A inhibitor H-89 abolished the corticosterone response of dispersed cells to galanin, while the phospholipase $\mathrm{C}$ inhibitor U-73122 and the PKC inhibitor calphostin-C were ineffective. We conclude that rat inner adrenocortical cells express GAL-R1 and GAL-R2 as mRNA and protein, and galanin stimulates corticosterone secretion acting via these receptor subtypes which are both coupled to the adenylate cyclase/PKA-dependent signaling pathway.
\end{abstract}

\section{Introduction}

Galanin is a regulatory peptide (30- and 29-amino acid residues in humans and rats, respectively) originally isolated

Correspondence to: Professor G.G. Nussdorfer, Department of Human Anatomy and Physiology, Section of Anatomy, University of Padua, Via Gabelli 65, I-35121, Padua, Italy

E-mail: gastone.nusdorfer@unipd.it

Key words: galanin, galanin receptors, adrenocortical cells, corticosterone secretion, adenylate cyclase, rat from pig intestine (1), which is widely distributed in both the central and peripheral nervous systems, where it acts as a neuromodulator (reviewed in ref. 2). Evidence suggests that galanin plays a role in the control of the hypothalamic CRH/ ACTH secretion-acting in an autocrine-paracrine manner. To summarize, galanin is colocalized with $\mathrm{CRH}$ in the paraventricular-nucleus neurons, and with ACTH in pituitary corticotrophs (3-7). Galanin administration slightly lowers basal ACTH plasma concentration and blunts ACTH response to $\mathrm{CRH}$ in healthy human volunteers (8) and inhibits ACTH release in vitro from rat corticotrophs (6), but enhances ACTH and glucocorticoid blood levels in both normal and ether-stressed rats (9).

Consistent findings suggest that the regulatory peptides, involved in the functional control of the central branch of the hypothalamic-pituitary-adrenal (HPA) axis, are also able to directly affect the secretory activity of adrenal cortex (reviewed in refs. 10-17). Accordingly, galanin was found to increase glucocorticoid secretion from both in situ perfused pig adrenals (18) and dispersed rat inner adrenocortical cells $(19,20)$. Findings also suggest that this last effect of galanin is mediated by galantide-sensitive receptors coupled to the adenylate cyclase-dependent cascade (21).

Three distinct subtypes of galanin receptors have been identified and cloned (GAL-R1, GAL-R2 and GAL-R3) (22), but their expression in the adrenal cortex has not yet been demonstrated. It, therefore, seemed worthwhile to investigate by reverse transcription (RT)-polymerase chain reaction (PCR) the expression of galanin receptor mRNA in adrenocortical cells, and to address the subtype(s) of receptor involved in the glucocorticoid-secretagogue action of galanin by the selective immuno-blockade of GAL-R1, GAL-R2 or GAL-R3.

\section{Materials and methods}

Reagents and animals. Rat galanin and $\left[{ }^{3} \mathrm{H}\right]$ galanin were purchased from Phoenix Pharmaceuticals (Belmont, CA), and goat polyclonal anti-GAL-R1 (C-20), anti-GAL-R2 (K-20) and anti-GAL-R3 (L-20) antibodies from Santa Cruz Biotechnology (Santa Cruz, CA). The signaling-cascade 
antagonists SQ-22536, U-73122, H-89 and calphostin-C (references in ref. 23) were obtained from Biomol Research Laboratories (Milan, Italy). Medium 199 was provided by Difco (Detroit, MI). ACTH, angiotensin-II (Ang-II), bovine serum albumin (BSA), human serum albumin (HSA), phosphate buffered saline (PBS), 3'-isobutyl-1-methylxantine (IBMX), and all other chemicals and laboratory reagents were purchased from Sigma-Aldrich Corporation (St. Louis, MO). Male Sprague-Dawley rats (200-250 g body weight) were provided by Charles-River (Como, Italy). Rats were decapitated and their adrenals were promptly removed. The protocol of the experiments was approved by the local Ethics Committee for Biomedical Studies.

Dispersed adrenocortical cells. Adrenals were decapsulated to separate zona glomerulosa, and then halved and enucleated to eliminate the medullary chromaffin tissue. Dispersed zona fasciculata-reticularis (inner) cells were obtained by sequential collagenase digestion and mechanical disagregation, as previously described $(24,25)$. Some mixed zona glomerulosa/ inner cell preparations were also prepared. Dispersed cells obtained from adrenals of 8 rats were pooled to obtain a single cell suspension, and 3 or 6 cell suspensions for each incubation experiment were used.

$R T-P C R$. Total RNA was extracted from dispersed cells and rat stomach, and reversed transcribed to cDNA (26-28). PCR was performed in a Delfi 100 thermal cycler (MJ Research Inc., Waterstone, MA), as previously detailed (29-31), using the primers for rat GAL-R1, GAL-R2 and GAL-R3 published by Anselmi et al (32). As positive control, the expression of the housekeeping gene glyceraldehyde-3-phosphate dehydrogenase (GAPDH) was detected, and to rule out the possibility of amplifying genomic DNA, one PCR was carried out without prior RT of the RNA. Detection of the PCR amplification products was performed by size fractionation on a $2 \%$ agarose-gel by electrophoresis. The specificity of the PCR was further verified by sequencing analysis as previously detailed (33). The primer sequence, the predicted size of the amplicons, and the PCR program are indicated in the legend of Fig. 2.

GAL-R immuno-blockade. Dispersed rat inner adrenocortical cells were put in Krebs-Ringer bicarbonate buffer with $0.2 \%$ glucose and $6 \mathrm{mg} / \mathrm{ml} \mathrm{BSA}$, and incubated $\left(10^{5}\right.$ cells $\left./ \mathrm{ml}\right)$ for $30 \mathrm{~min}$ at $37^{\circ} \mathrm{C}$ with increasing concentrations of anti-galanin receptor antibodies (1-6 $\mu \mathrm{g} / \mathrm{ml})$. Then, $10^{-8} \mathrm{M}\left[{ }^{3} \mathrm{H}\right]$ galanin was added, and the specimens were incubated for an additional $30 \mathrm{~min}$. Cells were harvested, washed three times in PBS, and the bound radioactivity was counted in a Wallac 1450 Microbeta Trilux counter (Perkin-Elmer, Life Science, Boston, MA) (34).

Experimental design. Dispersed rat inner or, where indicated, mixed zona glomerulosa/inner adrenocortical cells $\left(10^{5}\right.$ cells in $2 \mathrm{ml}$ Medium 199 and Krebs-Ringer bicarbonate buffer with $0.2 \%$ glucose and $5 \mathrm{mg} / \mathrm{ml} \mathrm{HSA}$ ) were incubated in duplicate as follows: i) galanin $\left(10^{-12}-10^{-6} \mathrm{M}\right)$ (corticosterone assay); ii) anti-GAL-R1, anti-GAL-R2, anti-GAL-R3 and antiGAL-R1 plus anti-GAL-R2 antibody $(5 \mu \mathrm{g} / \mathrm{ml})$ alone or in the

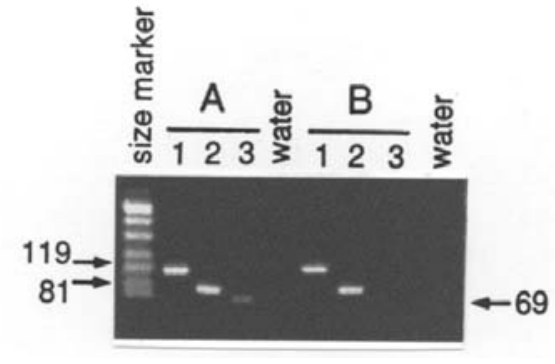

Figure 1. Ethidium bromide-stained $2 \%$ agarose gel showing cDNA amplified with rat GAL-R1- (1), GAL-R2- (2) and GAL-R3- (3) specific primers from the RNA of rat stomach (A) and dispersed inner adrenocortical cells (B). Primer sequences were: i) GAL-R1 sense, 5'-CCCCATC ATGTCATCCACCT-3' and GAL-R1 antisense, 5'-ATGGGGTTCAC CGAGGAGTT-3' (amplicon, 119 bp; U30290); ii) GAL-R2 sense, 5'-CA TCGTGGCGGTGCTTTT-3' and GAL-R2 antisense, 5'-AGCGGGA AGCGACCAAAC-3' (amplicon, 81 bp; NM019172); and iii) GAL-R3 sense, 5'-AGCCAAGCAGTACCACAG-3' and GAL-R3 antisense, 5'AGCACAGGATGAAGCAAA-3' (amplicon, 69 bp; NM019173). The PCR program was 35 cycles at $94^{\circ} \mathrm{C}$ for $30 \mathrm{sec}, 56^{\circ} \mathrm{C}$ (GAL-R1 and GAL-R2) or $57^{\circ} \mathrm{C}$ (GAL-R3) for $30 \mathrm{sec}$ and $72^{\circ} \mathrm{C}$ for $30 \mathrm{sec}$, followed by a final extension step at $72^{\circ} \mathrm{C}$ for $7 \mathrm{~min}$. Lane 1 was loaded with $200 \mathrm{ng}$ of a size marker (Marker VIII; Roche, Mannheim, Germany). No amplification with water instead of RNA is shown as negative control.

presence of $10^{-8} \mathrm{M}$ galanin (corticosterone cyclic-AMP [cAMP] assay); iii) SQ-22536 $\left(10^{-4} \mathrm{M}\right)$ alone and in the presence of $10^{-8} \mathrm{M}$ galanin or $10^{-9} \mathrm{M}$ ACTH (mixed adrenocortical-cell preparations, cAMP assay); iv) U-73122 $\left(10^{-5} \mathrm{M}\right)$ alone and in the presence of $10^{-8} \mathrm{M}$ galanin or $10^{-8} \mathrm{M}$ Ang-II (mixed adrenocortical-cell preparations, inositol triphosphate [IP3] assay); and v) SQ-22536 $\left(10^{-4} \mathrm{M}\right), \mathrm{U}-73122$ $\left(10^{-5} \mathrm{M}\right), \mathrm{H}-89\left(10^{-5} \mathrm{M}\right)$ or calphostin- $\mathrm{C}\left(10^{-5} \mathrm{M}\right)$ alone and in the presence of $10^{-8} \mathrm{M}$ galanin (corticosterone assay). The incubations were carried out in a shaking bath at $37^{\circ} \mathrm{C}$ for $60 \mathrm{~min}$ (corticosterone secretion) or $10 \mathrm{~min}$ (cAMP and IP3 production) in an atmosphere of $95 \%$ air $/ 5 \% \mathrm{CO}_{2}$. At the end of the experiments, the incubation tubes were centrifuged at $4^{\circ} \mathrm{C}$ at $100 \mathrm{x} \mathrm{g}$ for $10 \mathrm{~min}$, and the supernatants were stored at $-80^{\circ} \mathrm{C}$.

Corticosterone assay. Corticosterone was extracted from the incubation media and purified by HPLC (35), and its concentration was measured by RIA, as previously described (36); sensitivity, $50 \mathrm{pg} / \mathrm{ml}$; and intra- and interassay CVs, 7.6 and $8.9 \%$, respectively.

cAMP and IP 3 production. In the case of cAMP assay, the phosphodiesterase inhibitor IBMX $\left(10^{-4} \mathrm{M}\right)$ was added to prevent cAMP metabolism (23). cAMP was extracted by incubating the medium with $0.1 \mathrm{~N} \mathrm{HCl}$ for $20 \mathrm{~min}$ at $4^{\circ} \mathrm{C}$. The $\mathrm{HCl}$ extract was then neutralized, and the cAMP concentration was determined using the Biotrak TRK 432 kit (Amersham Pharmacia Biotech, Little Chalfont, UK); sensitivity, $1 \mathrm{pmol} / \mathrm{l}$; intra- and interassay CVs, 5.5 and $6.8 \%$, respectively. $\mathrm{IP}_{3}$ was extracted by the trichloroacetic acid method, purified by Amprep SAX-minicolumn chromatography, and its concentration was determined using the Biotrak TRK 1000 kit (Amersham Pharmacia Biotech.); sentitivity, 2 pmol/1; intra- and interassay CVs, 6.4 and 8.1\%, respectively. 


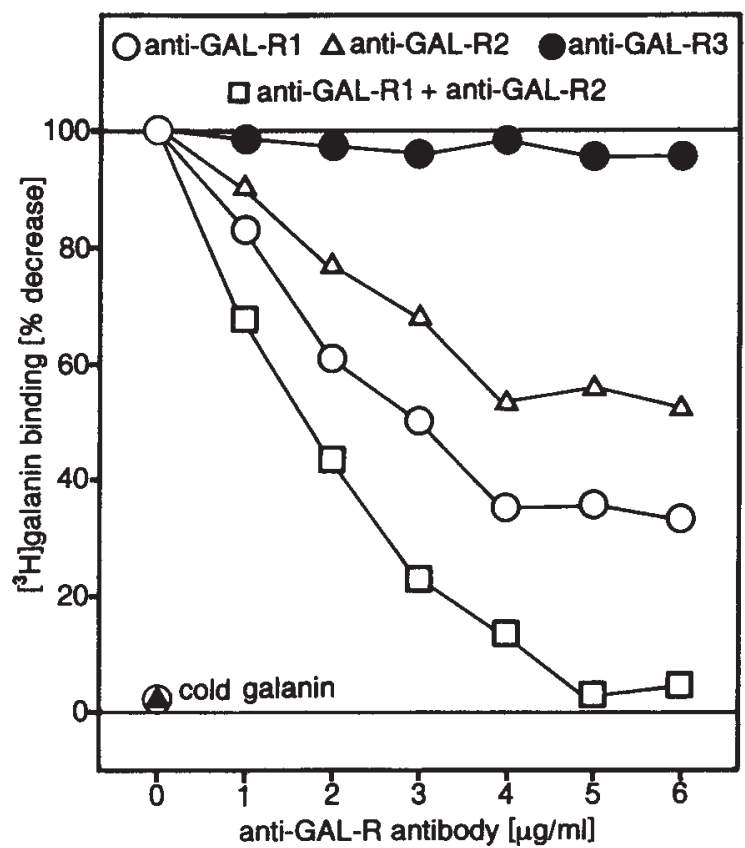

Figure 2. Effects of the galanin receptor immuno-blockade on $\left[{ }^{3} \mathrm{H}\right]$ galanin binding to dispersed rat inner adrenocortical cells. Data are expressed as percent change from control value (equalized to 100), and are the mean of three estimations.

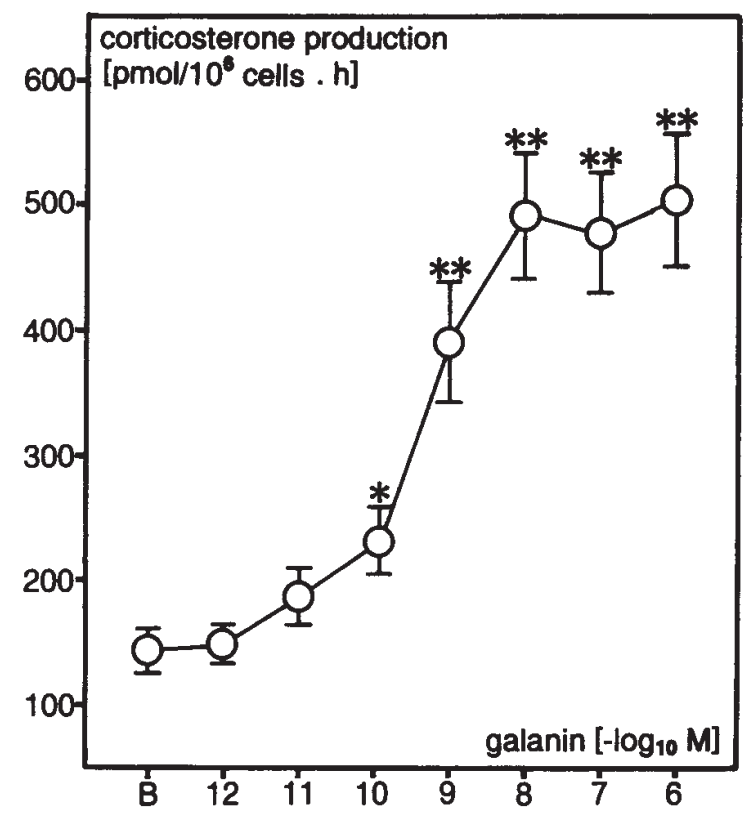

Figure 3. Effect of galanin on corticosterone secretion from dispersed rat inner adrenocortical cells. Data are means \pm SEM of three separate experiments. ${ }^{*} \mathrm{p}<0.05$ and ${ }^{* *} \mathrm{p}<0.01$ from baseline $(\mathrm{B})$ value.

Statistics. Data were expressed as means \pm SEM of the number of independent experiments indicated in the figure legends. Statistical analysis was carried out by ANOVA, followed by Duncan's multiple range test.

\section{Results}

RT-PCR showed the expression of the mRNAs of GAL-R1 and GAL-R2, but not GAL-R3, in rat inner adrenocortical

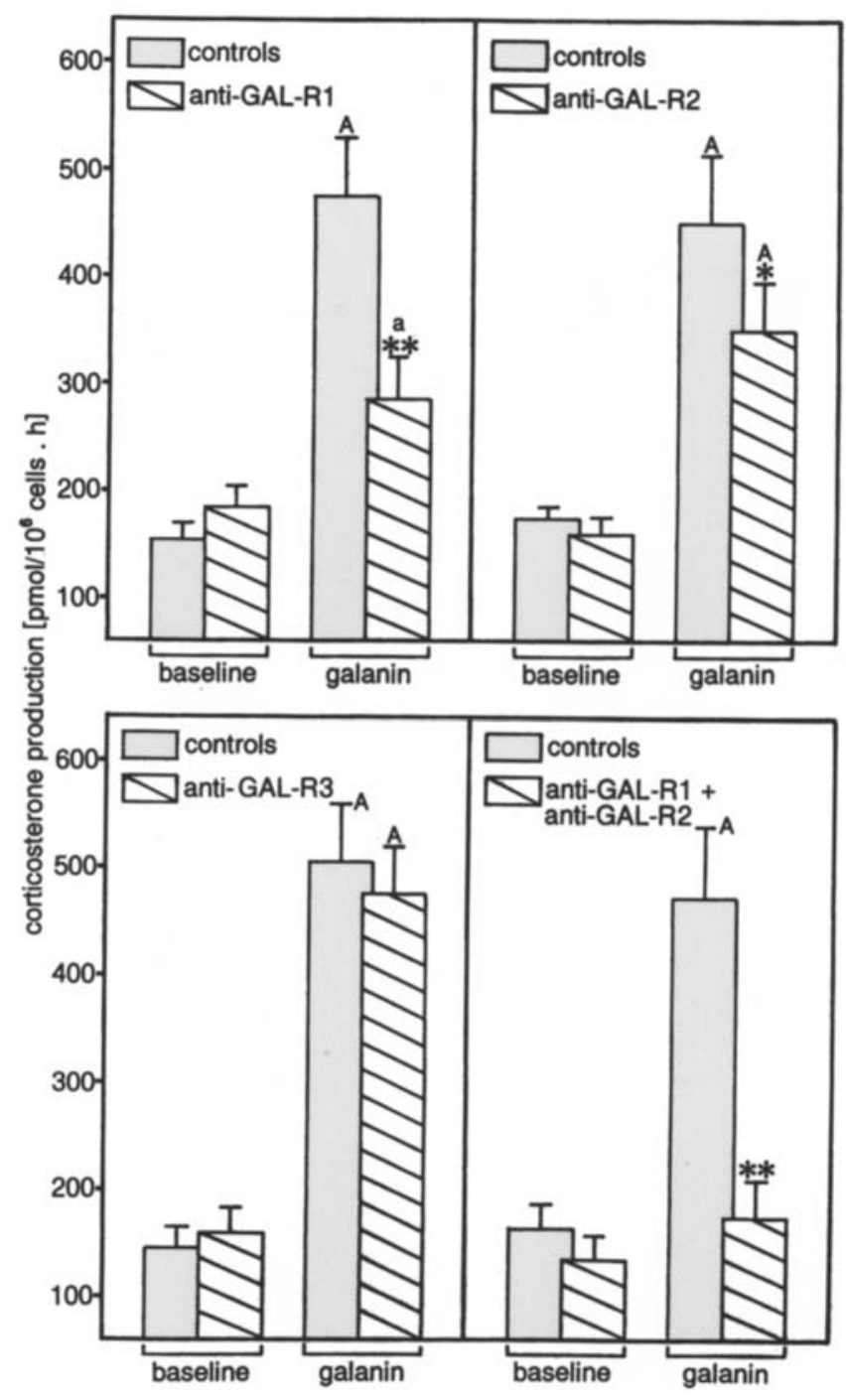

Figure 4. Effects of the galanin receptor immuno-blockade on basal and galanin $\left(10^{-8} \mathrm{M}\right)$-stimulated corticosterone secretion from dispersed rat inner adrenocortical cells. Bars are means \pm SEM of six separate experiments. ${ }^{*} \mathrm{p}<0.05$ and ${ }^{* *} \mathrm{p}<0.01$ from the respective control value; ${ }^{\mathrm{a}} \mathrm{p}<0.05$ and ${ }^{\mathrm{A}} \mathrm{p}<0.01$ from the respective baseline value.

cells. As expected (32), all three receptors were expressed in the rat stomach (Fig. 1).

The incubation with anti-GAL-R1 and anti-GAL-R2 antibodies concentration-dependently blocked $\left[{ }^{3} \mathrm{H}\right]$ galanin binding to dispersed rat inner adrenocortical cells. The maximal effective concentration was $4-5 \mu \mathrm{g} / \mathrm{ml}$, and evoked a $50 \%$ and $65 \%$ inhibition in the case of anti-GAL-R2 and anti-GAL-R1 antibodies, respectively. The incubation with 5 $\mu \mathrm{g} / \mathrm{ml}$ anti-GAL-R1 plus anti-GAL-R2 antibodies completely abolished the binding, as did the addition of $10^{-8} \mathrm{M}$ cold galanin. The exposure to the anti-GAL-R3 antibody was ineffective (Fig. 2). Hence, in the further functional studies, $5 \mu \mathrm{g} / \mathrm{ml}$ of antibodies was used to block the respective galanin receptor.

Galanin increased corticosterone secretion from dispersed rat inner adrenocortical cells in a concentration-dependent manner. The minimal and maximal effective concentrations were $10^{-10}$ and $10^{-8} \mathrm{M}$, and elicited $65 \%$ and $3-4$-fold increases, respectively (Fig. 3). Both anti-GAL-R1 and antiGAL-R2 antibodies dampened the corticosterone response of 

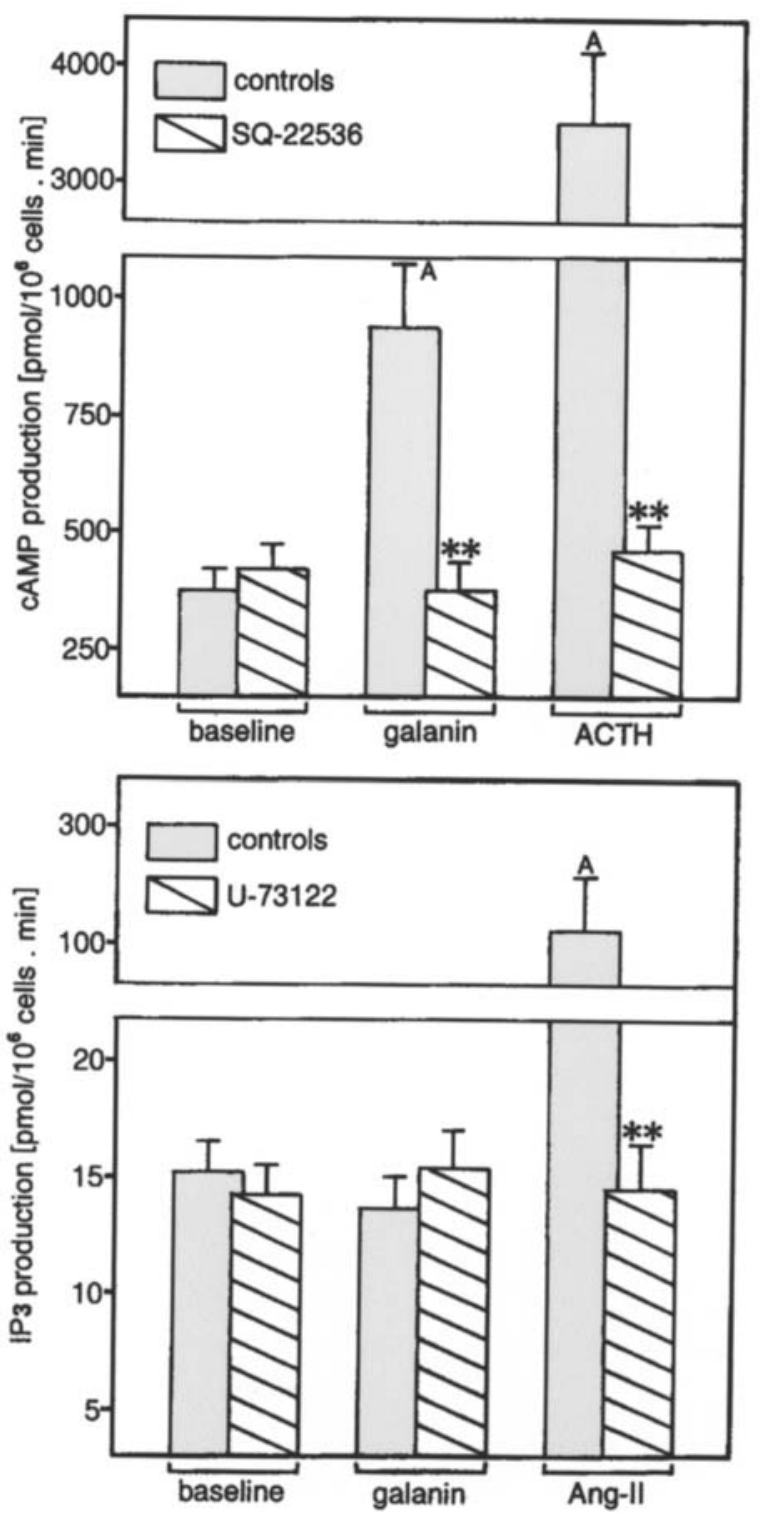

Figure 5. Effects of galanin $\left(10^{-8} \mathrm{M}\right)$ on cAMP (upper panel) and IP3 (lower panel) release from dispersed rat zona glomerulosa/inner adrenocortical cell mixture. cAMP response to galanin and ACTH $\left(10^{-9} \mathrm{M}\right)$ was suppressed by SQ-22536 $\left(10^{-4} \mathrm{M}\right)$, and IP3 response to Ang-II $\left(10^{-8} \mathrm{M}\right)$ by U-73122 $\left(10^{-5} \mathrm{M}\right)$. Bars are means \pm SEM of six separate experiments. ${ }^{* *} \mathrm{p}<0.01$ from the respective control value; ${ }^{A} p<0.01$ from the respective baseline value.

dispersed cells to $10^{-8} \mathrm{M}$ galanin, and when added together annulled it. Anti-GAL-R3 antibody was ineffective. The immuno-blockade of galanin receptors did not alter basal corticosterone secretion (Fig. 4).

Dispersed mixed adrenocortical cells displayed marked cAMP and IP3 responses to ACTH and Ang-II, respectively. These responses were suppressed by the adenylate cyclase inhibitor SQ-22536 $\left(10^{-4} \mathrm{M}\right)$ and the phospholipase C (PLC) inhibitor U-73122 $\left(10^{-5} \mathrm{M}\right)$, respectively. Galanin $\left(10^{-8} \mathrm{M}\right)$ elicited a significant rise in cAMP, but not IP3 release (Fig. 5). The cAMP response of dispersed rat inner adrenocortical cells to $10^{-8} \mathrm{M}$ galanin was lowered by both anti-GAL-R 1 and anti-GAL-R2 antibodies, and abrogated by the exposure to anti-GAL-R1 plus anti-GAL-R2 antibodies. Again, anti-GAL-R3 antibody was ineffective, and the galanin receptor immuno-

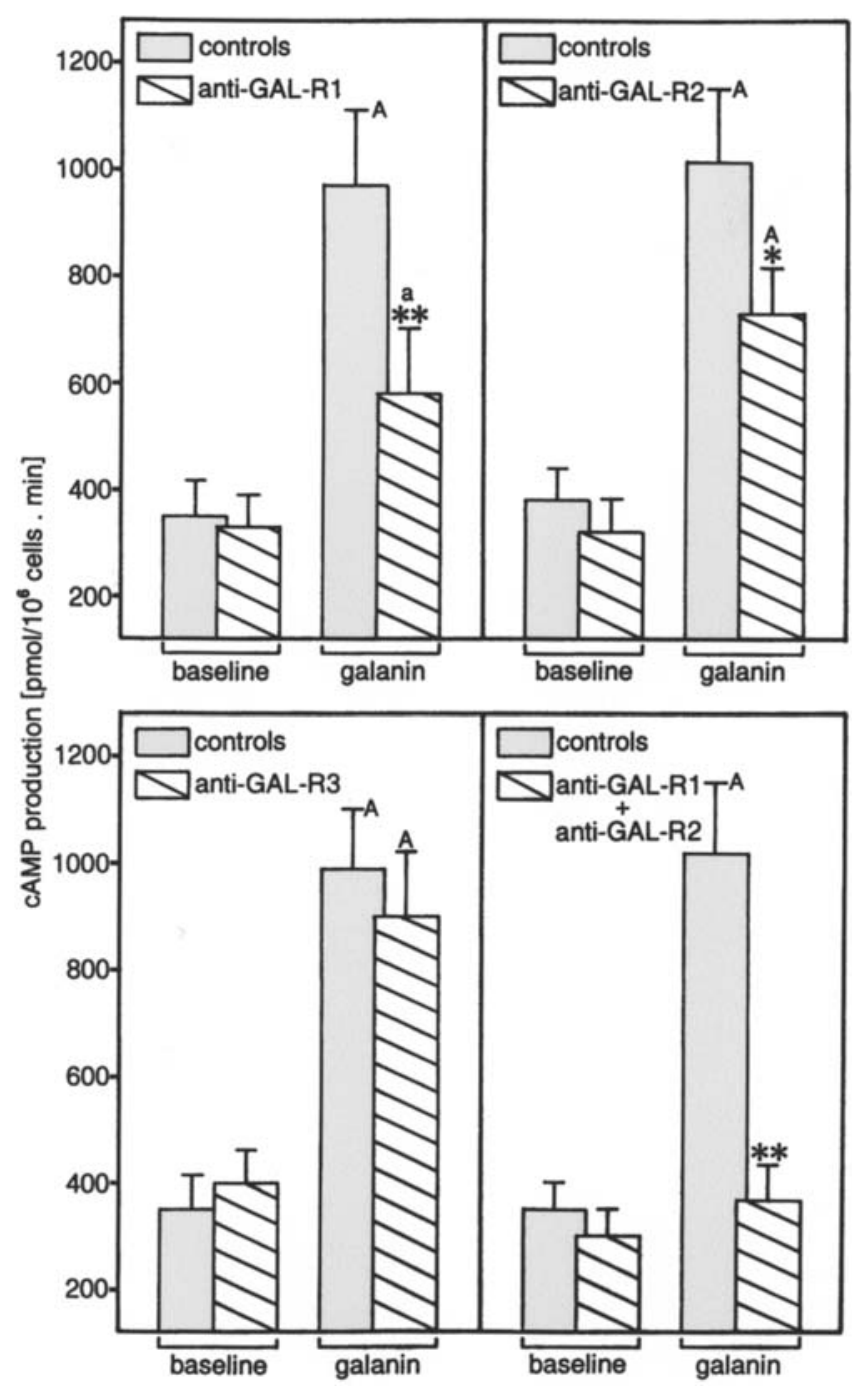

Figure 6. Effects of the galanin receptor immuno-blockade on basal and galanin $\left(10^{-8} \mathrm{M}\right)$-stimulated cAMP release from dispersed rat inner adrenocortical cells. Bars are means \pm SEM of six separate experiments. ${ }^{*} \mathrm{p}<0.05$ and ${ }^{* *} \mathrm{p}<0.01$ from the respective control value.

blockade did not evoke significant changes in basal cAMP release (Fig. 6).

The corticosterone response of dispersed rat inner adrenocortical cells was abrogated by both SQ-22536 $\left(10^{-4} \mathrm{M}\right)$ and the protein kinase $(\mathrm{PK}) \mathrm{A}$ inhibitor $\mathrm{H}-89\left(10^{-5} \mathrm{M}\right)$, and unaffected by either U-73122 $\left(10^{-5} \mathrm{M}\right)$ or the PKC inhibitor calphostin-C $\left(10^{-5} \mathrm{M}\right)$. Basal corticosterone secretion was unaffected by the inhibitors (Fig. 7).

\section{Discussion}

Our present investigation confirms previous findings indicating that galanin directly stimulates corticosterone secretion from rat inner adrenocortical cells, acting through receptors coupled to the adenylate cyclase-dependent cascade (see Introduction). However, the subtype of galanin receptor involved was not clarified, because the antagonists used (galantide and spantide) were non-specific (37).

Here we provide novel evidence that the glucocorticoid secretagogue effect of galanine is exclusively mediated by 


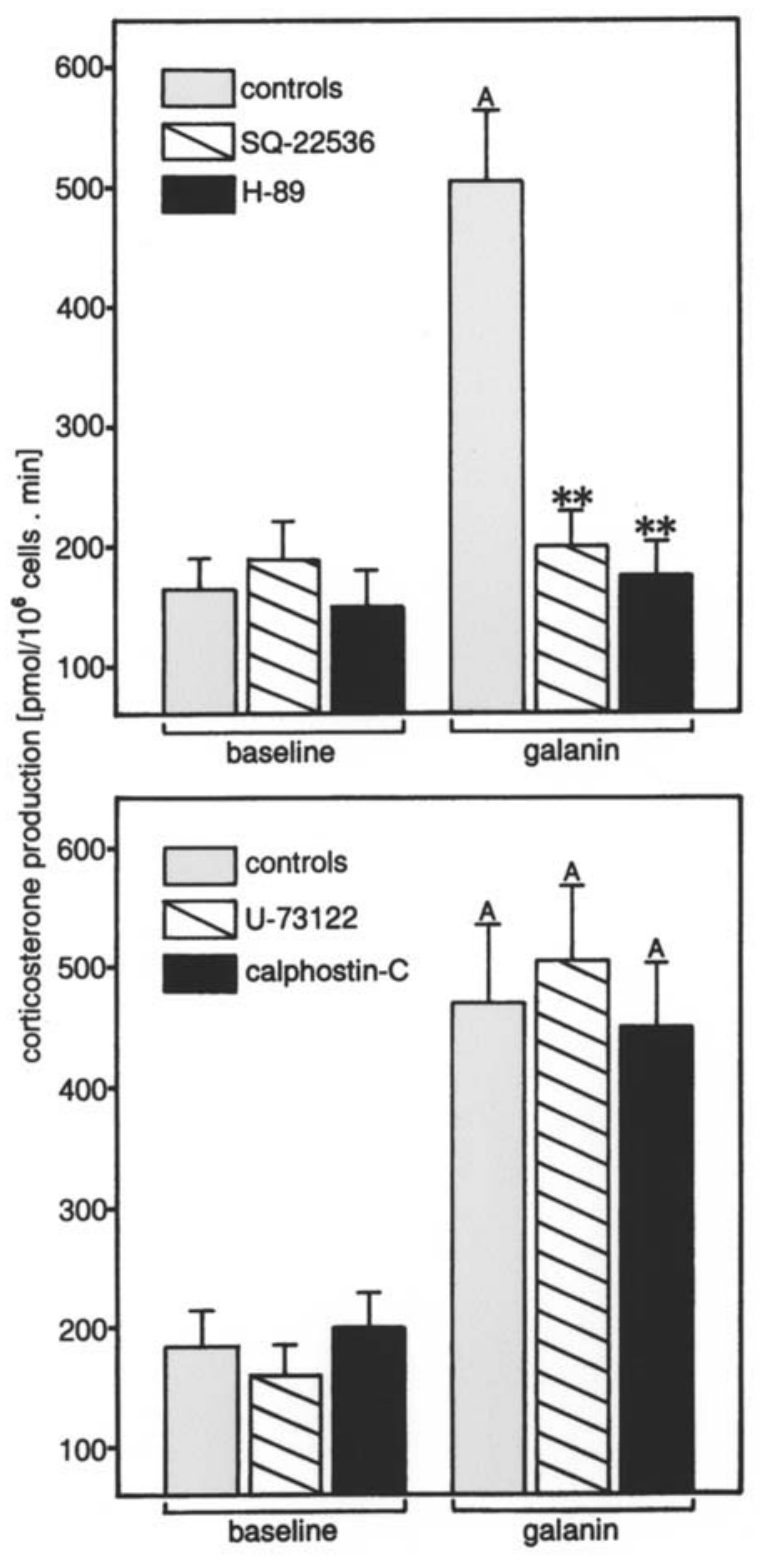

Figure 7. Effects of SQ-22536 (10-4 M), H-89 (10-5 M), U-73122 (10 $\left.0^{-5} \mathrm{M}\right)$ and calphostin- $\mathrm{C}\left(10^{-5} \mathrm{M}\right)$ on basal and galanin $\left(10^{-8} \mathrm{M}\right)$-stimulated corticosterone secretion from dispersed rat inner adrenocortical cells. Bars are means \pm SEM of six separate experiments. ${ }^{* *} \mathrm{p}<0.01$ from the respective control value; ${ }^{\mathrm{A}} \mathrm{p}<0.01$ from the respective baseline value.

GAL-R1 and GAL-R2. This contention is based on the following lines of evidence: i) PCR detected the expression of GAL-R 1 and GAL-R2, but not GAL-R3 mRNAs in dispersed rat inner adrenocortical cells, which rules out the possibility that stromal and vascular components of the gland account for this result. The expression of GAL-R3 was shown in the rat stomach, and this positive control makes it unlikely that technical factors (e.g. inadequate primers or the PCR program) prevented the detection of this receptor subtype in adrenocortical cells; ii) $\left[{ }^{3} \mathrm{H}\right]$ galanin binding to dispersed inner adrenocortical cells was displaced by antibodies against GAL-R1 and GAL-R2, but not GAL-R3. This observation indicates that GAL-R1 and GAL-R2 are expressed in adrenocortical cells not only as mRNAs, but also as functional proteins; and iii) corticosterone secretagogue action of galanin was counteracted by the exposure to anti-GAL-R1 and anti-GAL-R2, but not anti-GAL-R3 antibodies. The inhibitory effect of GAL-R1 or GAL-R2 immuno-neutralization was only partial, but the simultaneous blockade of both receptor subtypes completely abrogated the corticosterone response to galanin. This finding confirms that only GAL-R1 and GAL-R2 mediate the glucocorticoid secretagogue action of galanin.

Investigations aimed at pharmacologically characterizing galanin receptors indicate that GAL-R1 and GAL-R3 inhibit adenylate cyclase by activating pertussis toxin-sensitive Gi/o proteins, and GAL-R2 activates PLC via $\mathrm{G}_{\mathrm{q}} / 11$ proteins in the rat hypothalamus and intestine (38-40). Our study clearly shows that GAL-R1 and GAL-R2 are both positively coupled to the adenylate cyclase/PKA cascade in rat adrenocortical cells, which accords well with the view that the signaling mechanisms of receptors do vary depending on the tissue and cell types. The following pieces of evidence support this contention: i) galanin enhanced cAMP, but not $\mathrm{IP}_{3}$ production from dispersed rat adrenocortical cells; ii) the adenylate cyclase inhibitor SQ-22536, at a concentration able to abrogate the cAMP response to ACTH, abolished cAMP response to galanin; iii) the immuno-blockade of GAL-R1 and GAL-R2, but not GAL-R3, abrogated galanin-induced cAMP release from dispersed adrenocortical cells; iv) galanin did not alter IP 3 production from mixed zona glomerulosa/ inner adrenocortical cell suspensions, although these preparations exhibited a clearcut $\mathrm{IP}_{3}$ response to Ang-II, which was abrogated by the PLC antagonist U-73122; v) both SQ-22536 and the PKA antagonist H-89 suppressed the corticosterone response of dispersed inner adrenocortical cells to galanin, while U-73122 and the PKC inhibitor calphostin-C were ineffective; and finally vi) no signaling cascade inhibitor per se affected the basal corticosterone secretion over 60 min of static incubation, thereby excluding the possibility that their effect was due to a nonspecific toxic lesion of the inner adrenocortical cell steroidogenic machinery.

Collectively, our observations allow us to conclude that rat adrenocortical cells express GAL-R1 and GAL-R2, and galanin directly stimulates glucocorticoid secretion acting via these receptor subtypes, which are both coupled to the adenylate cyclase/PKA-dependent cascade. The physiological relevance of the secretagogue effect of galanin remains to be addressed. Under normal circumstances, the blood level of galanin in rats is in the limit of its minimal effective cooncentration as adrenocortical secretagogue $\left(\sim 10^{-10} \mathrm{M}\right)$ (41). However, evidence indicates that rat adrenomedullary cells are able to express galanin (42-44) and RIA-measurable galanin immunoreactivity was found in fresh rat adrenal medulla (45-47). Hence, it could be hypothesized that galanin should be included in that group of adrenomedullary peptides which are able to exert a paracrine control of the secretory activity of the adrenal cortex (10), and studies are underway to check this possibility.

\section{Acknowledgments}

We are indebted to Miss A. Coi for her outstanding secretarial support and help in the search and delivery of bibliographic items. 


\section{References}

1. Tatemoto K, Rökaeus A, Jörnvall H, McDonald TJ and Mutt V: Galanin. A novel biologically active peptide from porcine intestine. FEBS Lett 164: 124-128, 1989.

2. Bedecs K, Berthold M and Bartfai T: Galanin. 10 Years with a neuroendocrine peptide. Int J Biochem Cell Biol 27: 337-349, 1995.

3. Hsu DW, Hooi SC, Hedley-Whyte ET, Strauss RM and Kaplan LM: Coexpression of galanin and adrenocorticotropin hormone in human pituitary and pituitary adenomas. Am J Pathol 138: 897-909, 1991

4. Cimini V, Van Noorden S, Timson CM and Polak JM: Modulation of galanin and neuromedin U-like immunoreactivity in rat corticotropes after alteration of endocrine status. Cell Tissue Res 272: 137-146, 1993.

5. Merchenthaler I, Lopez FJ and Negro-Vilar A: Anatomy and physiology of central galanin-containing pathway. Prog Neurobiol 40: 711-769, 1993.

6. Cimini V: Galanin inhibits ACTH release in vitro and can be demonstrated immunocytochemically in dispersed corticotrophs. Exp Cell Res 228: 212-215, 1996

7. Leung B, Iisma TP, Leung KC, Hort YJ, Turner J, Sheehy JP and Ho KK: Galanin in human pituitary adenomas: frequency and clinical significance. Clin Endocrinol 56: 397-403, 2002.

8. Giustina A, Licini M, Schettino M, Doga M, Pizzocolo G and Negro-Vilar A: Physiological role of galanin in the regulation of anterior pituitary function in humans. Am J Physiol 266: E57-E61, 1994.

9. Malendowicz LK, Nussdorfer GG, Nowak KW and Mazzocchi G: The possible involvement of galanin in the modulation of the function of rat pituitary-adrenocortical axis under basal and stressful conditions. Endocr Res 20: 307-317, 1994.

10. Nussdorfer GG: Paracrine control of adrenal cortical function by medullary chromaffin cells. Pharmacol Rev 48: 495-530, 1996.

11. Nussdorfer GG, Rossi GP, Malendowicz LK and Mazzocchi G: Autocrine-paracrine endothelin system in the physiology and pathology of steroid secreting tissues. Pharmacol Rev 51: 403-438, 1999.

12. Glasow A and Bornstein SR: Leptin and the adrenal gland. Eur J Clin Invest 30: 39-45, 2000.

13. Nussdorfer GG: Proadrenomedullin-derived peptides in the paracrine control of the hypothalamo-pituitary-adrenal axis. Int Rev Cytol 206: 249-284, 2001.

14. Nussdorfer GG, Spinazzi R and Mazzocchi G: Cholecystokinin (CCK) and adrenal-cortex secretion. Vitam Horm 71: 433-453, 2005.

15. Spinazzi R, Andreis PG and Nussdorfer GG: Neuropeptide-Y and $\mathrm{Y}$-receptors in the autocrine-paracrine regulation of adrenal gland under physiological and pathophysiological conditions (Review). Int J Mol Med 15: 3-13, 2005.

16. Conconi MT, Spinazzi R and Nussdorfer GG: The endogenous ligands of PACAP/VIP receptors in the autocrine-paracrine regulation of the adrenal gland. Int Rev Cytol 249: 1-51, 2006.

17. Spinazzi R, Andreis PG, Rossi GP and Nussdorfer GG: Orexins in the regulation of the hypothalamic-pituitary-adrenal axis. Pharmacol Rev 58: 46-57, 2006.

18. Holst JJ, Ehrhart-Bornstein M, Messel T, Poulsen SS and Harling H: Release of galanin from isolated perfused porcine adrenal glands: role of splanchnic nerves. Am J Physiol 261: E31-E40, 1991

19. Mazzocchi G, Malendowicz LK and Nussdorfer GG: Galanin stimulates corticosterone secretion by isolated rat adrenocortical cells. Biomed Res 13: 181-184, 1992.

20. Mazzocchi G, Malendowicz LK, Rebuffat P and Nussdorfer GG: Effects of galanin on the secretory activity of the rat adrenal cortex: in vivo and in vitro studies. Res Exp Med 192: 373-381, 1992.

21. Mazzocchi G, Rebuffat P, Gottardo G, Malendowicz LK and Nussdorfer GG: Galanin stimulates glucocorticoid secretion in rats, through a receptor-dependent activation of the adenylate cyclase/protein kinase A-dependent signaling pathway. Peptides 19: 891-895, 1998

22. Branchek TA, Smith KE, Gerald C and Walker MW: Galanin receptor subtypes. Trends Pharmacol Sci 21: 109-117, 2000.

23. Mazzocchi G, Rebuffat P, Ziolkowska A, Rossi GP, Malendowicz LK and Nussdorfer GG: G protein receptors (GPR) 7 and 8 are expressed in human adrenocortical cells, and their endogenous ligands neuropeptides $\mathrm{B}$ and $\mathrm{W}$ enhance cortisol secretion by activating adenylate cyclase- and phospholipase C-dependent signaling cascades. J Clin Endocrinol Metab 90: 3466-3471, 2005.
24. Belloni AS, Rossi GP, Andreis PG, Neri G, Albertin G, Pessina AC and Nussdorfer GG: Endothelin adrenocortical secretagogue effect is mediated by the $\mathrm{B}$ receptor in rats. Hypertension 27: 1153-1159, 1996.

25. Spinazzi R, Petrelli L, Guidolin D, Carraro G, Casale V, Tortorella C, Neri G, Albertin G, Andreis PG and Nussdorfer GG: In vitro culture on Matrigel favors the long-term maintenance of rat zona glomerulosa-cell differentiated phenotype. Int $\mathbf{J}$ Mol Med 17: 1101-1110, 2006.

26. Albertin G, Carraro G and Nussdorfer GG: Human adrenomedullin gene silencing by short interfering RNAs: A preliminary study. Int J Mol Med 15: 579-583, 2005.

27. Andreis PG, Rucinski M, Neri G, Conconi MT, Petrelli L, Parnigotto PP, Malendowicz LK and Nussdorfer GG: Neuropeptides B and W enhance the growth of human adrenocortical carcinoma-derived NCI-H295 cells by exerting MAPK p42/p44-mediated proliferogenic and antiapoptotic effects. Int J Mol Med 16: 1021-1028, 2005.

28. Rucinski M, Andreis PG, Ziolkowska A, Nussdorfer GG and Malendowicz LK: Differential expression and function of beacon in the rat adrenal cortex and medulla. Int J Mol Med 16: $35-40,2005$

29. Albertin G, Carraro G, Petrelli L, Guidolin D, Neri G and Nussdorfer GG: Endothelin-1 and adrenomedullin enhance the growth of human adrenocortical carcinoma-derived SW-13 cell line by stimulating proliferation and inhibiting apoptosis. Int $\mathbf{J}$ Mol Med 15: 469-474, 2005.

30. Albertin G, Rucinski M, Carraro G, Forneris M, Andreis PG, Malendowicz LK and Nussdorfer GG: Adrenomedullin and vascular endothelium growth factor genes are over expressed in the regenerating rat adrenal cortex, and AM and VEGF reciprocally enhance their mRNA expression in cultured rat adrenocortical cells. Int J Mol Med 16: 431-435, 2005.

31. Rucinski M, Albertin G, Spinazzi R, Ziolkowska A, Nussdorfer GG and Malendowicz LK: Cerebellin in the rat adrenal gland: Gene expression and effects of CER and [des-Ser $\left.{ }^{1}\right]$ CER on the secretion and growth of cultured adrenocortical cells. Int $\mathrm{J}$ Mol Med 15: 411-415, 2005

32. Anselmi L, Lakhter A, Hirano AA, Tonini $M$ and Sternini C: Expression of galanin receptor messenger RNAs in different regions of the rat gastrointestinal tract. Peptides 26: 815-819, 2005.

33. Rossi GP, Sticchi D, Giuliani L, Bernante P, Zavattiero S, Pessina AC and Nussdorfer GG: Adiponectin receptor expression in the human adrenal cortex and aldosteroneproducing adenomas. Int J Mol Med 17: 975-980, 2006.

34. Spinazzi R, Ziolkowska A, Neri G, Nowak M, Rebuffat P, Nussdorfer GG, Andreis PG and Malendowicz LK: Orexins modulate the growth of cultured rat adrenocortical cell, acting through type 1 and type 2 receptors coupled to the MAPK p42/p44- and p38-dependent cascades. Int J Mol Med 15: 847-852, 2005.

35. Neri G, Malendowicz LK, Andreis PG and Nussdorfer GG: Thyrotropin-releasing hormone inhibits glucocorticoid secretion of rat adrenal cortex: in vivo and in vitro studies. Endocrinology 133: 511-514, 1993 .

36. Hochol A, Albertin G, Nussdorfer GG, Spinazzi R, Ziolkowska A, Rucinski M and Malendowicz LK: Effects of neuropeptides B and $\mathrm{W}$ on the secretion and growth of rat adrenocortical cells. Int J Mol Med 14: 843-847, 2004.

37. Crawley JN, Robinson JK, Langel U and Bartfai T: Galanin receptor antagonists M40 and C7 block galanin. Brain Res 600: 268-272, 1993.

38. Smith KE, Forray C, Walker HW, Jones KA, Tamm JA, Bard J, Branchek TA, Linemeyer and Gerald C: Expression and cloning of rat hypothalamic galanin receptor coupled to phosphoinositide turnover. J Biol Chem 272: 24612-24616, 1997.

39. Smith KE, Walker MW, Artymyshyn R, Bard J, Borowsky B, Tamm JA, Yao WJ, Vaysse PJJ, Branchek TA, Gerald C and Jones KA: Cloned human and rat galanin GAL-R3 receptors. Pharmacology and activation of G-protein inwardly rectifying $\mathrm{K}^{+}$channels. J Biol Chem 273: 23321-23326, 1998

40. Wang S, Hashemi T, Fried S, Clemmons AL and Hawes BE: Differential intracellular signaling of the GalR1 and GalR2 galanin receptor subtypes. Biochemistry 37: 6711-6717, 1998.

41. Vrontakis ME, Schroedter IC, Cosby H and Friesen HG: Expression and secretion of galanin during pregnancy in the rat. Endocrinology 130: 458-464, 1992.

42. Zentel HJ, Nohr D, Müller S, Yanaihara N and Weihe E: Differential occurrence and distribution of galanin in adrenal nerve fibres and medullary cells in rodents and avian species. Neurosci Lett 120: 167-170, 1990. 
43. Dagerlind A, Pelto-Huikko M, Lundberg JM, Ubink R, Verhofstad A, Brimijoin S and Hökfelt T: Immunologically induced sympathectomy of preganglionic nerves by antibodies against acetylcholinesterase: increased levels of peptides and their messenger RNAs in rat adrenal chromaffin cells. Neuroscience 62: 217-239, 1994.

44. Anouar Y and Eiden LE: Rapid and long-lasting increase in galanin mRNA levels in rat adrenal medulla following insulininduced reflex splanchnic nerve stimulation. Neuroendocrinology 62: 611-618, 1995.
45. Fischer-Colbrie R, Eskay RL, Eiden LE and Maas D: Transsynaptic regulation of galanin, neurotensin, and substance $\mathrm{P}$ in the adrenal medulla: combinatorial control by secondmessenger signaling pathways. J Neurochem 59: 780-783, 1992.

46. Holgert H, Dagerlind A, Hökfelt T and Lagercrantz H: Neuronal markers, peptides and enzymes in nerves and chromaffin cells in the rat adrenal medulla during postnatal development. Dev Brain Res 83: 35-52, 1994.

47. Mazzocchi G, Malendowicz LK, Macchi C and Nussdorfer GG: Evidence that endogenous galanin plays a role in the maintenance of the growth and steroidogenic capacity of rat adrenal zona fasciculata. Biomed Res 16: 51-57, 1995. 